\title{
The use of pulsed flushing to improve the efficiency of polymer floating media filters
}

\author{
Zhanna Govorova ${ }^{1}$, and Alexey Andrianov ${ }^{1, *}$ \\ ${ }^{1}$ Department of Water Supply and Sewerage, Moscow State University of Civil Engineering (National \\ Research University), Yaroslavskoe shosse 26, Moscow, 129337, Russia
}

\begin{abstract}
Surface runoff from urban area is a potential source of pollution of water bodies. The composition of pollutants in surface runoff depends on various factors and seasons. The main pollutants are oil products, suspended solids, COD, chlorides and other mineral salts. Traditional wastewater treatment plants include the mechanical removal of large items, debris and leaves; sand removal; water clarification in accumulating settling tanks; chemical dosing, contact filtration and deep purification on sorption filters. Filters with inert floating polystyrene media of various types are widely used as first stage filters. The operation of industrial filters in the technological schemes of wastewater treatment strongly depends on the backwash efficiency. Floating media flushing is carried out in the direction from top to down using the water accumulated in the over-filter space. The article presents the results of the study of pulsed flushing on a model plant. Experimental study was conducted on the real wastewater treatment plant. The kinetics of suspended solids and oil products removal from filter media was studied. The operational parameters and mode of pulsed flushing were determined. The research results were used during the reconstruction of Moscow surface runoff water treatment plants.
\end{abstract}

\section{Introduction}

The main contaminants of the surface runoff from urban areas are suspended solids, petroleum products, COD, chlorides, etc. Furthermore, recently there has been a significant pollution of surface runoff with heavy metals, deicing agents and surface-active agents [1-10].

The design of treatment facilities depends on their capacity, quality of surface wastewater from urban areas and requirements for its purification level [11-14]. Wastewater treatment plants generally include: mechanical stage using bar or mesh screens and grit chambers, water clarification in settling tanks which also work as flow equalization basins; removal of the bulk of organic and mineral contaminants using sedimentation, flotation or contact filtration with preliminary reagent treatment; advanced treatment of residual mechanical impurities with petroleum products and organic matter adsorbed on

\footnotetext{
${ }^{*}$ Corresponding author: alexei-waterlab@yandex.ru
} 
them using mechanical filtration on standard deep bed filters; advanced treatment using activated carbon filters to remove residual dissolved petroleum products and other organic compounds; disinfection of treated wastewater to be discharged back into water bodies or to be reused for industrial water supply.

Various types of polymer floating media filters are used for contact filtration [12-15]; some of them are presented in the Table 1.

Table 1. Types of filters with floating polymer loading.

\begin{tabular}{|c|c|c|}
\hline Type & Name & Specification \\
\hline $\begin{array}{c}\text { Contact filter with } \\
\text { floating media }\end{array}$ & $\begin{array}{c}\text { CFPZ-1, } \\
\text { (FPZ-1) }\end{array}$ & $\begin{array}{c}\text { Upward filtration through a heterogeneous floating } \\
\text { media }\end{array}$ \\
\hline $\begin{array}{c}\text { Hydraulic automatic } \\
\text { floating media filter }\end{array}$ & AFPZ-4 & $\begin{array}{c}\text { Downward filtration through a heterogeneous } \\
\text { floating media (A - automatic flushing) }\end{array}$ \\
\hline $\begin{array}{c}\text { Clarifying and sorption } \\
\text { contact filter with } \\
\text { floating media }\end{array}$ & CFPZ (CS) & $\begin{array}{c}\text { Two compartment filter. } \\
\text { Downward filtration through polystyrene floating } \\
\text { media, followed by downward filtration through a } \\
\text { sorption media }\end{array}$ \\
\hline
\end{tabular}

Flushing of floating media filters is carried out by a downward water stream from the space above the filter bed. The granules of filter media remain motionless at low speed of water movement. The head of water passing through pores of granular bed is partially spent on overcoming the friction force at the surface of the granules. When the value of hydrodynamic pressure becomes equal to the mass of the filtration media in the water, the filter layer expands, its porosity increases, the granules switch from the stationary state to the condition of irregular motion in a definite volume [15].

Flushing is an important procedure of the filtration process. The key factors affecting the efficiency of granular media flushing are: flushing intensity; the duration of the washing of granules surface from adhering suspended solids and sediment; media expansion ratio; the degree of uniformity of distribution and collection of flush water. The main goal of the filter flushing is adjusting flushing intensity and expansion ratio which guarantee almost complete washing of the granules from adhering contaminants. The uneven collection and distribution of flush water over the filter surface area may cause a local expansion of the media and washout of polystyrene granules with the flush water. Excessive expansion of the floating media during flushing leads to necessity for an increase of the construction height of the filter body and capital investment.

Progressive clogging and oiling of the upper layer may occur due to reagentless filtration of wastewater that contains petroleum products and suspended solids and due to insufficiently effective flushing. The consequences are a sharp increase of the initial headloss in the filter media, a reduction of the filtration duration time and a decrease in the overall efficiency of the filter installation.

To intensify the flushing process a series of short pulses is used that are aimed at more efficient washing of the granular media from suspended solids and adsorbed petroleum products. The investigation of this flushing procedure is an urgent engineering problem and was the objective of the experiments described below.

\section{Materials and methods}

The flushing efficiency of industrial filters FPZ-4 and FPZ-1, which were a part of surface runoff treatment facility (Moscow), was studied. At all treatment facilities the water used for flushing was either treated (FPZ-1) or clarified in intermittent settling tanks (FPZ-4). 
A pilot plant was installed in the filtering chamber of the treatment facility (Fig. 1) to investigate impulsive flushing of the floating filter media. It included pilot filter with polystyrene floating media, equipped with pipes, shutoff and control valves, and samplers. Pipe fitting allowed carrying out upward (FPZ-1) and downward (FPZ-4) filtration. Characteristics of floating media are given in Table 2 .
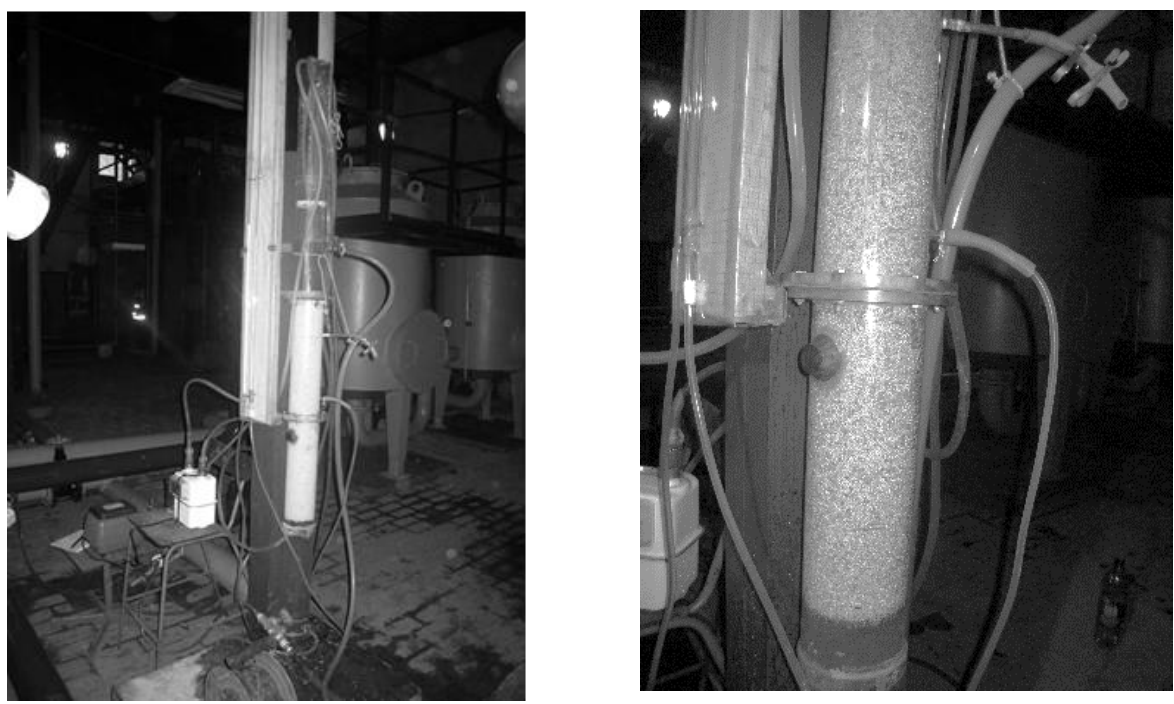

Fig. 1. General view and fragments of the pilot plant.

The pilot plant was supplied with water from the last section of the settling tank. Flow rate did not exceed $10 \mathrm{~m} / \mathrm{h}$. Filtration time ranged from 10 to 14 hours. Pulsed water flushing included a short-time supply of treated water from the space above the filter bed with the intensity of 35-40 L/m $\mathrm{m}^{2} \cdot \mathrm{s}$ during the first 30-60 seconds and then flushing with reduced intensity down to $7-10 \mathrm{~L} / \mathrm{m}^{2} \cdot \mathrm{s}$ for the next 3-5 minutes. A criterion for the evaluation of flushing effectiveness is the rate of washing out of contaminants - suspended solids and petroleum products. Flushing effectiveness was evaluated separately for three different layers of filter media, comparing the contamination degree (dirt-holding capacity) of these layers throughout the filtration cycle.

Table 2. Filter media characteristics.

\begin{tabular}{|c|c|c|}
\hline Layer number & Grain size, $\mathbf{~ m m}$ & Layer thickness, $\mathbf{m}$ \\
\hline 1 & $1-1.5$ & 0.05 \\
\hline 2 & $1.5-3$ & 0.65 \\
\hline 3 & $4-8$ & 0.1 \\
\hline
\end{tabular}

Flush water was sampled at regular intervals of $0.5-1$ minute. The amount of suspended solids was determined by the gravimetric method (PND F 14.1:2:4.254-2009). The mass concentration of petroleum products was determined by IR spectroscopy with pre-extraction of emulsified and dissolved petroleum products from water with carbon tetrachloride and its separation from the related organic compounds of other classes in a column filled by aluminum oxide (PND F 14.1:2.116-97). 


\section{Results and discussion}

At the first stage of experiments, the analysis of water flushing efficiency of industrial filters operating in reagentless mode was carried out. Influent wastewater entering the FPZ-1 and FPZ-4 filters has the concentration of suspended solids up to $250 \mathrm{mg} / \mathrm{L}$, petroleum products - up to $5.5 \mathrm{mg} / \mathrm{L}$. Grain size of filter media was $2-4 \mathrm{~mm}$, layer thickness $-1.5-1.6 \mathrm{~m}$. The flow rate in nominal operating mode did not exceed $8 \mathrm{~m} / \mathrm{h}$. Flushing intensity was $12-15 \mathrm{~L} / \mathrm{m}^{2} \cdot \mathrm{s}$.

The results showed that at the appointed washing rate contaminants were discharged too slowly over time (Table 3 ).

Table 3. The concentration of suspended solids (SS) and petroleum products (PP) in the flush water after industrial filters.

\begin{tabular}{|c|c|c|c|c|}
\hline \multirow{2}{*}{ Washing time, min. } & \multicolumn{2}{|c|}{ FPZ-1 } & \multicolumn{2}{c|}{ FPZ-4 } \\
\cline { 2 - 5 } & $\mathrm{SS}, \mathrm{mg} / \mathrm{L}$ & $\mathrm{PP}, \mathrm{mg} / \mathrm{L}$ & $\mathrm{SS}, \mathrm{mg} / \mathrm{L}$ & $\mathrm{PP}, \mathrm{mg} / \mathrm{L}$ \\
\hline 0.5 & 1100 & 9.4 & 150 & 9.8 \\
\hline 1 & 1500 & 7.1 & 720 & 7.6 \\
\hline 2 & 1800 & 3.4 & 2250 & 4.7 \\
\hline 3 & 1320 & 2.5 & 1740 & 3.4 \\
\hline 4 & 640 & 2.1 & 1050 & 3.0 \\
\hline 5 & 230 & 1.8 & 300 & 2.0 \\
\hline 6 & 150 & 0.9 & 160 & 1.8 \\
\hline 7 & 80 & 0.8 & 150 & 1.5 \\
\hline
\end{tabular}

With a washing time of 7 minutes, a sufficiently large amount of suspended solids $(50-150 \mathrm{mg} / \mathrm{L})$ and petroleum products $(0.8-1.5 \mathrm{mg} / \mathrm{L})$ remained in the flush water.

Insufficient intensity of floating media flushing leads to the accumulation of residual contamination in the layer of large polystyrene granules. Performing a flushing with constant high intensity $\left(35-40 \mathrm{~L} / \mathrm{sec}^{2} \mathrm{~m}^{2}\right)$ leads to $2.5-3$ times excessive consumption of flush water and to an increase of the pipe diameters of the underdrainage.

Therefore, an alternative method of flushing the filter bed media was chosen for further research - this is pulsed downward flushing that uses purified water, accumulated in the space above the filter bed. The duration of filtration cycle was set at 14 hours. The concentration of suspended solids in wastewater entering the pilot plant was $35-90 \mathrm{mg} / \mathrm{L}$, petroleum products $-2.6-3.2 \mathrm{mg} / \mathrm{L}$. Dirt-holding capacity per filter cycle did not exceed $4.14 \mathrm{~kg} / \mathrm{m}^{3}$ and $0.073 \mathrm{~kg} / \mathrm{m}^{3}$ for SS and PP respectively.

The impulsive flushing mode was as follows: for the $1^{\text {st }}$ minute the intensity was $39.5 \mathrm{~L} / \mathrm{m}^{2} \cdot \mathrm{s}$, and then for the next 5 minutes the intensity did not exceed $9 \mathrm{~L} / \mathrm{m}^{2} \cdot \mathrm{s}$. The results of experiments, during which the mode of accumulation and distribution of the forming sediment and petroleum products in the interporous space of filter media was changing, are shown in Fig. 2 and 3. 


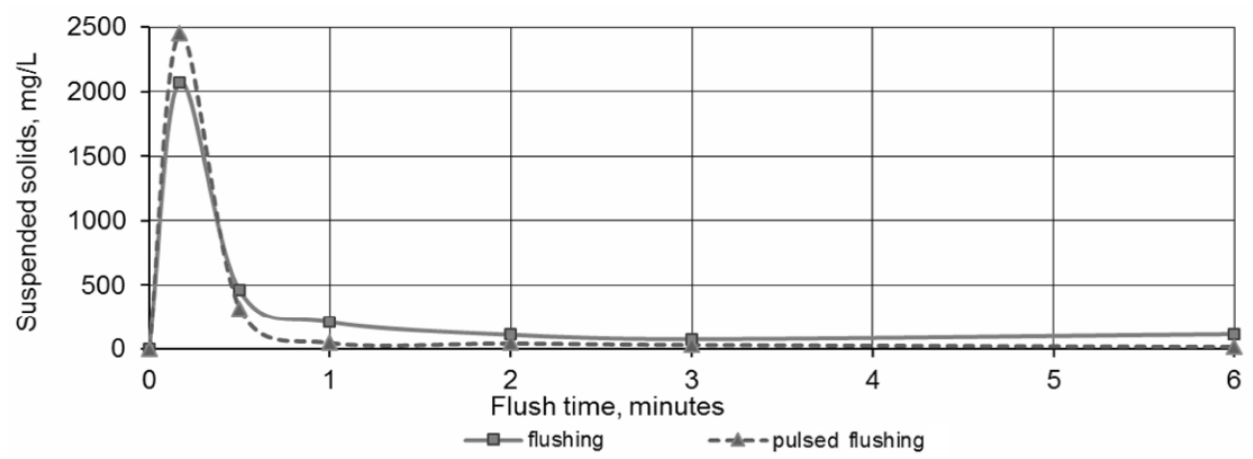

Fig. 2. The kinetics of the washing out of suspended solids during the flushing of FPZ-1 filter.

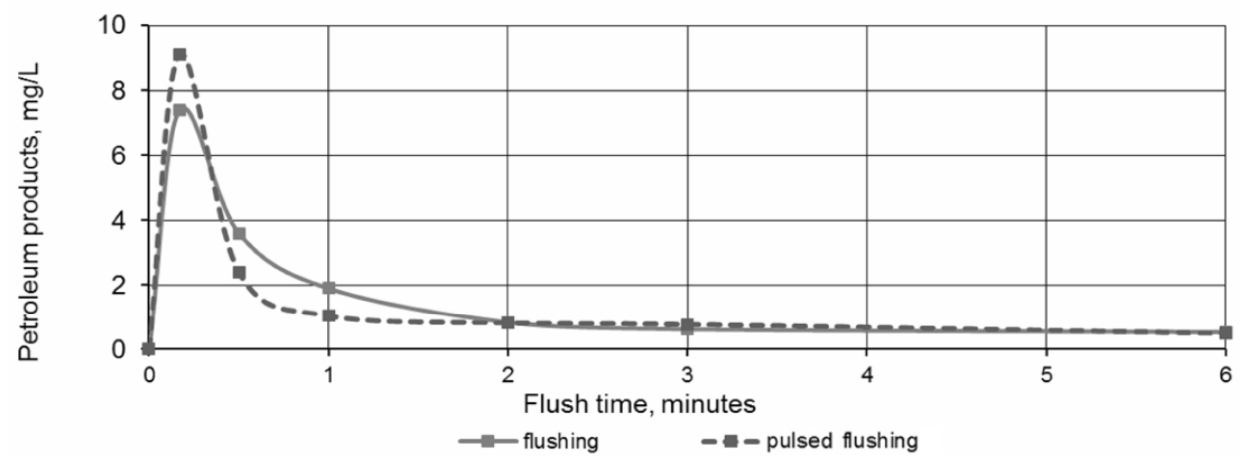

Fig. 3. The kinetics of the washing out of petroleum products during the flushing of FPZ-1 filter.

As can be seen from the graphs, during the pulsed flushing with the intensity of $39.5-9 \mathrm{~L} / \mathrm{m}^{2} \cdot \mathrm{s}$ compared to flushing with constant intensity of $15 \mathrm{~L} / \mathrm{m}^{2} \cdot \mathrm{s}$ for 6 minutes, the amount of contaminants washed out increases by $18-25 \%$ in the first $20 \mathrm{sec}$.

Pulsed flushing with a short-time intensity of $39.5 \mathrm{~L} / \mathrm{m}^{2} \cdot \mathrm{s}$ provides an increase of the expansion ratio of large-granular layer with a density of $60-80 \mathrm{~kg} / \mathrm{m}^{3}$ within $30-40 \%$ and mixing of the granules. Therefore, contaminants that are washed out from large-granular layer then transported through the expanded layers of smaller granules during next 3-5 minutes of flushing and then washed out from the model filter.

The results of conducted research have been introduced into industrial treatment facility with a capacity of $4000 \mathrm{~m}^{3} /$ day, its general view is shown in Fig. 4 .
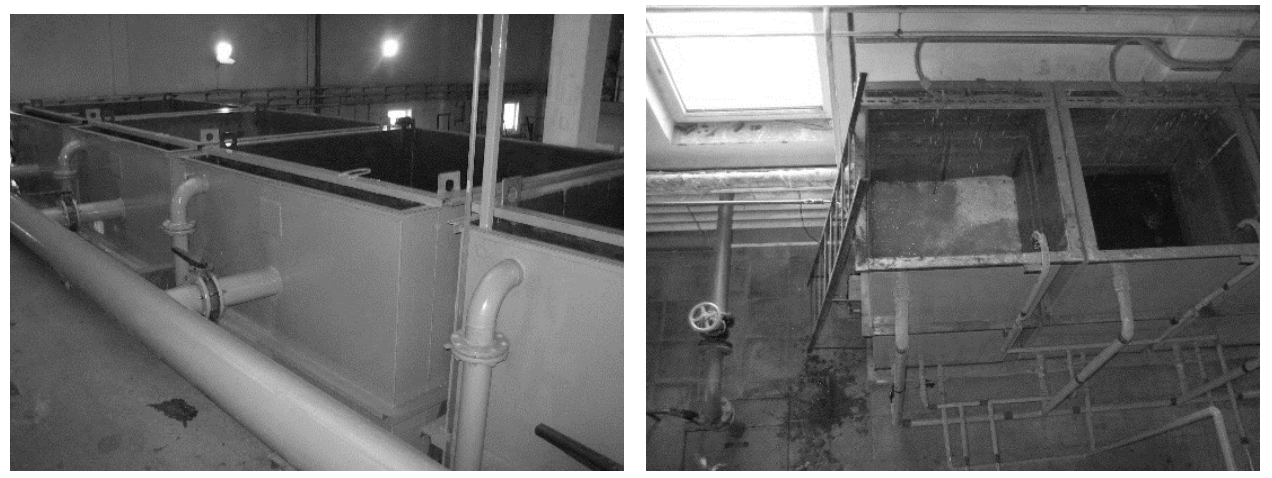

Fig. 4. Industrial filters FPZ-1 (Moscow). 


\section{Conclusions}

The analysis of the flushing process of industrial filters with floating polystyrene media revealed that after flushing with constant intensity up to $15 \mathrm{~L} / \mathrm{m}^{2} \cdot \mathrm{s}$ for 7 minutes a large amount of suspended solids $(50-150 \mathrm{mg} / \mathrm{L})$ and petroleum products $(0.8-1.5 \mathrm{mg} / \mathrm{L})$ remained in a flush water. It demonstrates that granules of the load are not clean enough and might lead to accumulation of contaminants and reduction of the filter cycle.

As an alternative method, impulsive flushing, with the intensity of $35-40 \mathrm{~L} / \mathrm{m}^{2} \cdot \mathrm{s}$ for the first 30-60 sec and reduced intensity of $7-10 \mathrm{~L} / \mathrm{m}^{2} \cdot \mathrm{s}$ for the next $3-5$ minutes, was studied. It was established that in the first 30-60 sec the amount of contaminants carried out with the flush water increases and by the end of the flushing concentration of suspended solids and petroleum products left in water is no more than $10 \mathrm{mg} / \mathrm{L}$ and $1.0 \mathrm{mg} / \mathrm{L}$, respectively.

The results of conducted research were adopted for the reconstruction of Moscow surface runoff treatment plants.

\section{References}

1. M. A. Alekseyev, A.M. Kurganov, Organizatsiya otvedeniya poverkhnostnogo (dozhdevogo i talogo stoka) s urbanizirovannymi territoriyami (ASV, Moscow, 2000)

2. E. D. Palagin, A. K. Strelkov, P. G. Bykova, A. V. Tsypin, D. V. Vdovin, Water Supply and Sanitary Tech. 12, 41-46 (2016)

3. E. D. Palagin, M. A. Gridneva, P. G. Bykova, A. A. Pavlukhin, Water Supply and Sanitary Tech. 12, 28-35 (2018)

4. G. Ignatavičius, V. Valskys, I. Bulskaya, D. Paliulis, A. Zigmontienè, J. Satkūnas, Estonian J. of Earth Sci. 66, 1, 13-20 (2017)

5. R. Buzier, M. H. Tusseau-Vuillemin, M. Keirsbulck, J. M. Mouchel, Phys. and Chem. of the Earth 36, 500-505 (2011)

6. S. Marshall, V. Pettigrove, M. Carew, A. Hoffmann, Envir. Pollut. 158, 1716-1725 (2010)

7. M. Scholz, S. Kazemi Yazdi, Water Air Soil Pollut. 198, 55-64 (2009)

8. M. Zhang, H. Chen, J. Wang, G. Pan, J. of Environ. Sci. 22, 1, 40-46 (2010)

9. R. H. Kim, S. Lee, Y. M. Kim, J. H. Lee, S.K. Kim, S. G. Kim, Environ. Technol. 26, 411-420 (2005)

10. J. W. Zhao, B. Q. Shan, C. Q. Yin, Techniques and Equip. for Environ. Pollut. Control 7, 12, 14-17 (2006)

11. Rekomendatsii po raschetu sistem sbora, otvedeniya i ochistki poverkhnostnogo stoka $s$ selitebnykh territoriy, ploshchadok predpriyatiy i opredeleniyu usloviy vypuska yego $v$ vodnyye ob"yekty (NII VODGEO, Moscow, 2014)

12. M. G. Zhurba, Zh. M. Govorova, O. B. Govorov, Water Supply and Sanitary Tech. 3, 25-29 (2003)

13. Zh. M. Govorova, Regulirovaniye $i$ ochistka poverkhnostnykh stochnykh vod: problemnyy doklad (VNIINTPI, Moscow, 2005)

14. M. G. Zhurba, Zh. M. Govorova, O. B. Govorov, Vodoochistka. Vodopodgotovka. Vodosnabzheniye 1, 29-34 (2008)

15. M. G. Zhurba, Vodoochistnyye fil'try s plavayushchey zagruzkoy (Moscow, 2011)

16. C. Weidemann, S. Vogt, H. Nirschl, J. of Food Eng. 132, 29-38 (2014) 